\title{
Hyperthermia enhances the sensitivity of pancreatic cancer SW1990 cells to gemcitabine through ROS/JNK signaling
}

\author{
HANGBIN JIN $^{1,2}$, YANYAN ZHAO ${ }^{2}$, JIANFENG YANG ${ }^{1}$, XIAOFENG ZHANG $^{1}$ and SHENGLIN MA ${ }^{2}$ \\ Departments of ${ }^{1}$ Gastroenterology and ${ }^{2}$ Oncology, Hangzhou First People's Hospital, \\ Nanjing Medical University, Hangzhou, Zhejiang 310006, P.R. China
}

Received August 10, 2017; Accepted May 25, 2018

DOI: $10.3892 / \mathrm{ol} .2018 .9455$

\begin{abstract}
Pancreatic cancer (PC) is a highly aggressive type of cancer. Gemcitabine (GEM) is a standard chemotherapeutic treatment of advanced PC; however, it requires improvement, and more effective therapeutic methods must be further explored. In the present study, hyperthermia combined with GEM was used on the PC cell line SW1990. The results revealed that mild hyperthermia (at $42^{\circ} \mathrm{C}$ ) effectively increased the inhibitory effect of GEM on cell viability, as determined using an MTT assay, and increased the effect of GEM-induced apoptosis, as determined using an Annexin V-fluorescein isothiocyanate/propidium iodide assay, in PC SW1990 cells. Additionally, it resulted in increased S-phase arrest, downregulated the expression of the anti-apoptosis protein B-cell lymphoma 2 and upregulated the expression of the pro-apoptosis protein Bcl-2-associated $\mathrm{X}$ protein, cleaved caspase- 3 and cleaved caspase- 9 , as determined using a reverse transcription-quantitative polymerase chain reaction and western blot analysis. Furthermore, it was revealed that hyperthermia resulted in the rapid generation of reactive oxygen species (ROS) and substantial activation of c-Jun-N-terminal kinase (JNK). The introduction of ROS and JNK inhibitors suppressed hyperthermia-induced apoptosis in GEM-treated cells, suggesting that hyperthermia increased GEM cytotoxicity in PC SW1990 cells by inducing apoptosis via the ROS/JNK signaling pathway.
\end{abstract}

\section{Introduction}

Pancreatic cancer (PC) is the fourth leading cause of cancer mortality globally with an estimated 5-year survival rate of only 7\% in $2010(1,2)$, and its clinical course is aggressive. When diagnosed, $80-95 \%$ of patients present locally advanced

Correspondence to: Dr Shenglin Ma, Department of Oncology, Hangzhou First People's Hospital, Nanjing Medical University, 261 Huansha Road, Hangzhou, Zhejiang 310006, P.R. China E-mail: shlinma@163.com

Key words: pancreatic cancer, hyperthermia, gemcitabine, viability, apoptosis, reactive oxygen species/c-Jun-N-terminal kinase signaling or metastatic disease (3) as symptoms are unobservable at the early stages of PC (4). Thus, few patients undergo surgical resection at an early stage, whilst the majority of patients are treated with chemotherapy, which often combines gemcitabine (GEM) with other chemotherapeutics, at advanced stages $(5,6)$.

GEM, as an antitumor drug, is used for the treatment of advanced PC (7). Chemotherapy always results in toxicity, yet counteracting this by using low concentrations of GEM limits its efficacy, resulting in reduced overall survival rates of patients with PC $(8,9)$. Therefore, methods for enhancing GEM efficacy must be explored. It has been demonstrated that heating a tumor up to a temperature of $\sim 42^{\circ} \mathrm{C}$ may synergistically enhance the antitumor effect of $\operatorname{GEM}(10,11)$; however the underlying mechanism remains unclear.

In the present study, the PC cell line SW1990 was used to investigate the effect of hyperthermia on GEM antitumor activity. When treated with hyperthermia at a temperature of $42^{\circ} \mathrm{C}$, SW1990 cells exposed to GEM demonstrated decreased viability and increased apoptosis with the upregulation of apoptosis-activating genes. Additionally, a higher number of cells treated using hyperthermia combined with GEM were arrested in the S-phase stage of the cell cycle in comparison with the control group treated with GEM alone, a process in which survivin may be involved (12). Furthermore, the underlying mechanism of apoptosis caused by hyperthermia combined with GEM in PC cells was examined, and it was revealed that reactive oxygen species (ROS)/c-Jun N-terminal kinase (JNK) signaling was involved.

\section{Materials and methods}

Cell culture. The human PC SW1990 cell line was obtained from the Cell Resource Centre at Peking Union Medical College (Beijing, China). Cells were cultured in RPMI-1640 medium (Gibco; Thermo Fisher Scientific, Inc., Waltham, MA, USA) supplemented with $10 \%$ fetal bovine serum (Lonza Group, Ltd., Basel, Switzerland), $5 \mathrm{mM} \mathrm{L-glutamine,} 5 \mathrm{mM}$ non-essential amino acids, $100 \mathrm{U} / \mathrm{ml}$ penicillin-streptomycin (Invitrogen; Thermo Fisher Scientific, Inc.), in a humidified $5 \% \mathrm{CO}_{2}$ incubator at $37^{\circ} \mathrm{C}$.

Viability assay. Cell viability was evaluated using an MTT assay (Sigma-Aldrich; Merck KGaA, Darmstadt, Germany). A total of $1 \times 10^{4}$ SW1990 cells were seeded into each well of 
a 96-well plate in $100 \mu \mathrm{l}$ RPMI-1640 medium and incubated with $0,1,5,10$ and $20 \mu \mathrm{M}$ GEM (Selleck Chemicals, Houston, TX, USA) for $12,24,48$ and $72 \mathrm{~h}$ at $37^{\circ} \mathrm{C}$ in a $5 \% \mathrm{CO}_{2}$ incubator. Then, cells were incubated with $20 \mu \mathrm{l}$ of $5 \mathrm{mg} / \mathrm{ml}$ MTT (Sigma-Aldrich, St. Louis, MO, USA) at $37^{\circ} \mathrm{C}$ for $4 \mathrm{~h}$, and then cells were lysed at room temperature for $10 \mathrm{~min}$ following the addition of $200 \mu \mathrm{l}$ dimethyl sulfoxide (DMSO; OriGene Technologies, Inc., Rockville, MD, USA), which was used to dissolve the formazan crystals. Absorbance was measured at $490 \mathrm{~nm}$ using a Rainbow microplate reader (Tecan Group, Ltd., Männedorf, Switzerland). Cell viability was expressed as a percentage of the untreated control.

Apoptosis assay. A total of $1 \times 10^{6}$ SW1990 cells were seeded on $60 \mathrm{~mm}$ dishes and grown to $80 \%$ confluence, and then treated with or without hyperthermia at $42^{\circ} \mathrm{C}$ for $90 \mathrm{~min}$ in the presence or absence of $10 \mu \mathrm{M}$ JNK inhibitor Sp600125 (Selleck Chemicals) or $5 \mathrm{mM}$ ROS inhibitor $\mathrm{N}$-acetyl-L-cysteine (NAC; Selleck Chemicals), followed by $5 \mu \mathrm{M}$ GEM treatment at $37^{\circ} \mathrm{C}$ for 24 h. Cells were collected, washed three times with PBS and resuspended in PBS. Apoptosis was analyzed using an Annexin V-fluorescein isothiocyanate (FITC)/propidium iodide (PI) detection kit (cat. no. 556547; BD Biosciences, Franklin Lakes, NJ, USA), according to the manufacturer's protocol. Briefly, the cells were washed three times with PBS and then incubated for $15 \mathrm{~min}$ at room temperature in the dark in $100 \mu \mathrm{l}$ of $1 \mathrm{X}$ Annexin binding buffer containing $5 \mu \mathrm{l}$ Annexin V-FITC and $2 \mu \mathrm{l}$ PI. The quantity of phosphatidylserine on the outer surface of the plasma membrane (a biochemical alteration unique to the membranes of apoptotic cells) and the quantity of PI, a dye that easily enters dead cells or cells in the late stages of apoptosis and binds DNA, but does not bind to the plasma membrane of viable cells, was detected. Fluorescence was detected using a FACSCalibur flow cytometer by fluorescence-activated cell sorting (FACS; Accuri C6 Flow Cytometer; BD Biosciences) analysis, and data were analyzed using CellQuestPro version 5.2 software (BD Biosciences). Cells with phosphatidylserine on their surface were considered to be apoptotic (early apoptotic cells in addition to late apoptotic cells). Cell cycle distribution was analyzed using FACS and CFlow Plus software version 1.0 (BD Biosciences) (13). Briefly, $1 \times 10^{5}$ cells were seeded into 12 -well plates to reach $80 \%$ confluence by the next day. Cells were treated with or without hyperthermia at $42^{\circ} \mathrm{C}$ for $90 \mathrm{~min}$, followed by $5 \mu \mathrm{M}$ GEM treatment at $37^{\circ} \mathrm{C}$ for $24 \mathrm{~h}$. Cells were collected, washed three times with PBS and incubated in staining buffer $(0.1 \%$ sodium citrate, $0.1 \%$ Triton $\mathrm{X}-100$ and $50 \mu \mathrm{g} / \mathrm{ml}$ propidium iodide) at $4^{\circ} \mathrm{C}$ for $1 \mathrm{~h}$. Cell cycle phases were determined according to the content of DNA in cells, as follows: Phase $\mathrm{G}_{1}$, DNA replication has not started and the content of DNA is the lowest; phase $\mathrm{G}_{0}$ cells contain the least amount of DNA; phase $S$, cells replicate and progress from 1xDNA to $2 x D N A$; phase $\mathrm{G}_{2}$, DNA doubles to 2xDNA; phase $\mathrm{M}$, cell division and 2xDNA in cells. DNA was presented using PI staining and thus cell cycle phases were determined. Cell cycle distribution was measured using CFlow Plus software version 1.0.

Morphological analysis of cells. A total of $1 \times 10^{6}$ SW1990 cells were seeded into four culture flasks at a density of $1 \times 10^{6} / \mathrm{ml}$ and allowed to reach $75-80 \%$ confluence. PC SW1990 cells were treated with or without hyperthermia at $42^{\circ} \mathrm{C}$ for $90 \mathrm{~min}$, followed by $5 \mu \mathrm{M}$ GEM treatment at $37^{\circ} \mathrm{C}$ for $24 \mathrm{~h}$. The control and treated cells were dislodged using EDTA/bovine serum albumin solution, made up into a suspension and washed twice with PBS. The cell fixation was performed as previously described by Hobot et al (14). Briefly, each cell suspension was mixed rapidly with an equal volume of $2 \%$ glutaraldehyde solution in $0.1 \mathrm{M}$ cacodylate buffer and fixed at $4^{\circ} \mathrm{C}$ for $2 \mathrm{~h}$. The pellet of cells, following centrifugation at $1,000 \mathrm{x}$ g at $4^{\circ} \mathrm{C}$ for $5 \mathrm{~min}$, was resuspended twice in an excess of $0.1 \mathrm{M}$ cacodylate buffer for a 15 -min interval. Cells were resuspended in $1 \%$ osmium tetroxide in $0.1 \mathrm{M}$ cacodylate buffer and fixed at $4^{\circ} \mathrm{C}$ for $30 \mathrm{~min}$, and then centrifuged at $1,000 \mathrm{x} \mathrm{g}$ at $4^{\circ} \mathrm{C}$ for $5 \mathrm{~min}$. Then, $0.1 \mathrm{M}$ cacodylate buffer was added and fixed at $4^{\circ} \mathrm{C}$ for $30 \mathrm{~min}$, and then centrifuged at $1,000 \mathrm{x}$ g at $4^{\circ} \mathrm{C}$ for $5 \mathrm{~min}$. To the pellet, an equal volume of $2 \%$ agar in $0.1 \mathrm{M}$ sodium cacodylate buffer (heated to $40^{\circ} \mathrm{C}$ ) was added, and then the agar and cells were mixed rapidly. Following cooling, the pellet was cut with a razor blade into 2-mm cubic pieces and stored in $2 \%$ glutaraldehyde solution at $4^{\circ} \mathrm{C}$ until further processing and viewing using a transmission electron microscope (OPTON EM 900; Zeiss AG, Oberkochen, Germany; magnification, x6,000).

Western blot analysis. A total of $1 \times 10^{6}$ SW1990 cells were seeded on $60 \mathrm{~mm}$ dishes and grown to $80 \%$ confluence. Cells were collected and washed twice with PBS, and then lysed $4^{\circ} \mathrm{C}$ for 15 min using lysis buffer [50 mM Tris- $\mathrm{HCl}(\mathrm{pH} 7.4), 1 \mathrm{mM}$ EDTA, $1 \%$ NP40, $150 \mathrm{mM} \mathrm{NaCl}, 10 \mathrm{mM} \mathrm{NaF}, 1 \mathrm{mM} \mathrm{Na}_{3} \mathrm{VO}_{4}$ )] containing a protease inhibitor cocktail (Roche Molecular Diagnostics, Branchburg, NJ, USA). Following centrifugation at $12,000 \mathrm{x} \mathrm{g}$ for $10 \mathrm{~min}$ at $4^{\circ} \mathrm{C}$, the supernatant was collected and quantified using a bicinchoninic acid quantification kit (Beyotime Institute of Biotechnology, Haimen, China). A total of $50 \mu \mathrm{g}$ protein per lane samples were separated via 10\% SDS-PAGE (Bio-Rad Laboratories, Inc., Hercules, CA, USA) and transferred to polyvinylidene fluoride membranes (EMD Millipore, Billerica, MA, USA). The membranes were blocked using 5\% non-fat dried milk in Tris-buffered saline with $0.05 \%$ Tween-20 for $1 \mathrm{~h}$ at room temperature, and incubated with the following specific primary antibodies overnight at $4^{\circ} \mathrm{C}$ : Mouse monoclonal immunoglobulin $\mathrm{G}(\mathrm{IgG})$ for B-cell lymphoma 2 (Bcl-2; 1:500; cat no. sc7382), rabbit polyclonal IgG for Bcl-2-associated X protein (Bax; 1:500; cat no. sc493), mouse monoclonal IgG for $\beta$-actin (1:1,000; cat no. sc47778), rabbit polyclonal IgG for Survivin (1:500; cat no. sc-10811; all Santa Cruz Biotechnology, Inc., Dallas, CA, USA), rabbit polyclonal IgG for cleaved-caspase-3 (1:1,000; cat no. 9661S) and for cleaved-caspase-9 (1:1,000; cat no. 9505; both Cell Signaling Technology, Inc., Danvers, MA, USA). Rabbit polyclonal antibodies specific for phosphorylated (p-)JNK (1:1,000; cat no. 9251) and JNK (1:1,000; cat no. 9252 ; both Cell Signaling Technology, Inc.) were used for detection, followed by the horseradish peroxidase-conjugated goat anti-mouse secondary antibody (1:2,000; cat no. sc-2005) and anti-rabbit IgG antibody (1:2,000; cat no. sc-2004) (both from Santa Cruz Biotechnology, Inc.) for $2 \mathrm{~h}$ at room temperature. Enhanced chemiluminescence-detecting reagent (GE Healthcare, Chicago, IL, USA) was used for development. The gray value of the targeted bands was analyzed using QuantityOne software version 4.6.2 (Bio-Rad Laboratories, Inc.) subsequent to incubation; $\beta$-actin was detected as the internal reference. 
A

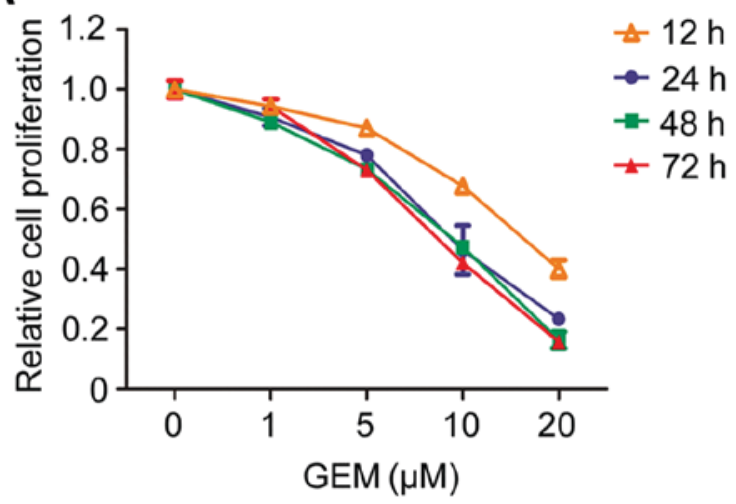

B

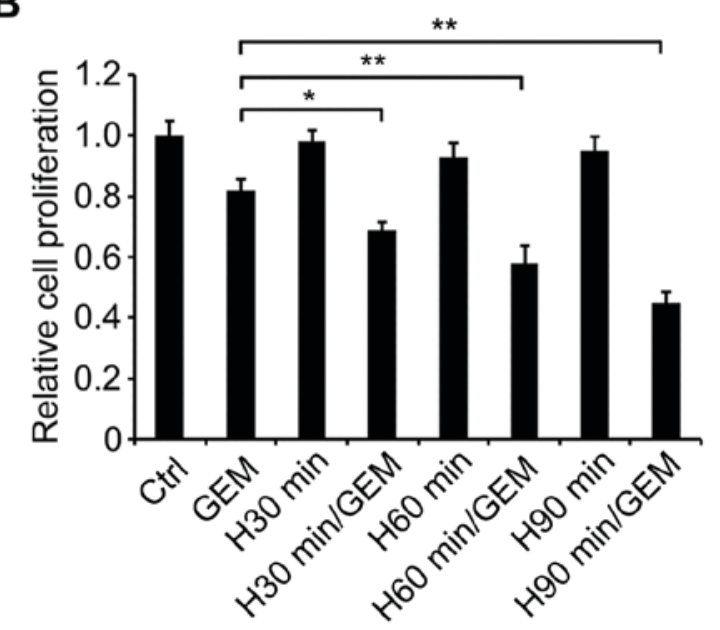

Figure 1. Hyperthermia enhances the inhibitory effect of GEM on viability in SW1990 cells. (A) SW1990 cells were treated with 0, 1, 5, 10 and $20 \mu \mathrm{M}$ GEM for 12, 24, 48 and $72 \mathrm{~h}$. Cell viability was assessed using an MTT assay. (B) Cells were treated with hyperthermia at $42^{\circ} \mathrm{C}$ for different durations (30, 60 or $90 \mathrm{~min}$ ), and then were treated using $5 \mu \mathrm{M}$ GEM for $24 \mathrm{~h}$. Cell viability was assessed using an MTT assay. ${ }^{*} \mathrm{P}<0.05$ and ${ }^{* *} \mathrm{P}<0.01$ with comparisons shown by lines. Ctrl, untreated group; GEM, treated with gemcitabine alone; H30 min, treated with hyperthermia alone for $30 \mathrm{~min}$; H30 min/GEM, treated with hyperthermia for $30 \mathrm{~min}$ in addition to gemcitabine; H60 min, treated with hyperthermia alone for $60 \mathrm{~min}$; H60 min/GEM, treated with hyperthermia for $60 \mathrm{~min}$ in addition to gemcitabine; H90 min, treated with hyperthermia alone for $90 \mathrm{~min}$; $\mathrm{H} 90 \mathrm{~min} / \mathrm{GEM}$, treated with hyperthermia for $90 \mathrm{~min}$ in addition to gemcitabine.

Detection of ROS production. A total of $5 \times 10^{5}$ SW1990 cells were seeded in 6-well plates overnight and then treated with or without hyperthermia at $42^{\circ} \mathrm{C}$ for $90 \mathrm{~min}$, followed by $5 \mu \mathrm{M}$ GEM treatment at $37^{\circ} \mathrm{C}$ for $24 \mathrm{~h}$. Following treatment, the cells were collected and stained with $10 \mu \mathrm{M}$ 2',7'-dichlorofluorescin diacetate at $37^{\circ} \mathrm{C}$ for $30 \mathrm{~min}$ in the dark. Fluorescence was detected using a FACSCalibur flow cytometer (BD Biosciences) using a FITC channel, and data were analyzed using CellQuestPro version 5.2 software.

Statistical analysis. Data were obtained from at least three experiments. Statistical analysis was preformed using SPSS 13.0 for Windows (SPSS, Inc., Chicago, IL, USA). Values are expressed as the mean \pm standard error of the mean. One-way analysis of variance was used to assess differences between groups. The Duncan method was employed for pairwise comparison and was followed by Bonferroni's correction.
$\mathrm{P}<0.05$ was considered to indicate a statistically significant difference.

\section{Results}

Hyperthermia increases the inhibition of GEM on the viability of PC SW1990 cells. To investigate the effect of GEM on PC cell viability, the human SW1990 PC cell line with high metastatic ability was used in the present study. SW1990 cells were exposed to various concentrations of GEM for different durations (Fig. 1A). An MTT assay was performed in order to evaluate cell viability. The results revealed that GEM treatment inhibited cellular viability in a dose-dependent manner at 12,24, 48 and $72 \mathrm{~h}$ treatment durations and that the viability decrease trends were similar amongst the 24,48 and $72 \mathrm{~h}$ groups, which demonstrated a sharper decrease compared with the $12 \mathrm{~h}$ group (Fig. 1A). Of the treatment concentrations, $5 \mu \mathrm{M}$ GEM exerted a slight inhibitory effect on the viability of SW1990 cells and was selected to be used in subsequent experiments due to a lower cytotoxicity compared with relatively high concentrations of GEM. SW1990 cells were treated with different temperatures $\left(40^{\circ} \mathrm{C}, 42^{\circ} \mathrm{C}\right.$ or $\left.44^{\circ} \mathrm{C}\right)$ for 90 min with or without GEM. The results revealed that $42^{\circ} \mathrm{C}$ treatment alone did not significantly result in heat-induced cytotoxicity compared with the $44^{\circ} \mathrm{C}$ alone treatment, whereas the $42^{\circ} \mathrm{C}$ hyperthermia treatment may mostly enhance the role of GEM on inhibiting cell viability relative to $40^{\circ} \mathrm{C}$ treatment (data not shown). Hence, the temperature of the hyperthermia treatment was selected to be $42^{\circ} \mathrm{C}$. Following this, SW1990 cells were treated with mild hyperthermia at $42^{\circ} \mathrm{C}$ for 30,60 or 90 min with and without GEM, followed by GEM treatment for $24 \mathrm{~h}$ at $37^{\circ} \mathrm{C}$, and then cell viability was assessed. The results indicated that $42^{\circ} \mathrm{C}$ hyperthermia for 30,60 and 90 min significantly enhanced the inhibitory effect of GEM on cell viability compared with GEM alone $(\mathrm{P}<0.05, \mathrm{P}<0.01$ and $\mathrm{P}<0.01$, respectively), whilst hyperthermia treatment alone without GEM resulted in low heat-induced toxicity and did not significantly affect cell viability compared with GEM alone (Fig. 1B). These results suggested that hyperthermia served a promoting function on the inhibitory effect of GEM on PC cell viability.

Hyperthermia enhances GEM-induced apoptosis in SW1990 cells. To confirm the effect of hyperthermia on GEM-induced apoptosis in PC SW1990 cells, an Annexin V-FITC/PI assay was performed. Cells with phosphatidylserine on their surface (indicating that they were either early apoptotic cells or late apoptotic cells) were considered to be apoptotic. The result revealed that hyperthermia treatment alone did not significantly increase the cell apoptosis compared with the untreated control cells, whilst GEM-treated cells revealed significantly upregulated apoptosis compared with the control group $(\mathrm{P}<0.01)$. However, hyperthermia significantly increased GEM-induced cell apoptosis compared with the cells treated with GEM alone $(\mathrm{P}<0.01$; Fig. 2A). Additionally, apoptotic bodies could be clearly observed in PC cells treated with hyperthermia combined with GEM (Fig. 2B). Meanwhile, SW1990 cells at the $G_{0} / G_{1}$ stage, $S$ stage and $G_{2} / M$ stage were analyzed using flow cytometry (Fig. 2C). The results indicated that the percentage of PC cells at the S-phase stage was significantly increased following treatment with $42^{\circ} \mathrm{C}$ hyperthermia 

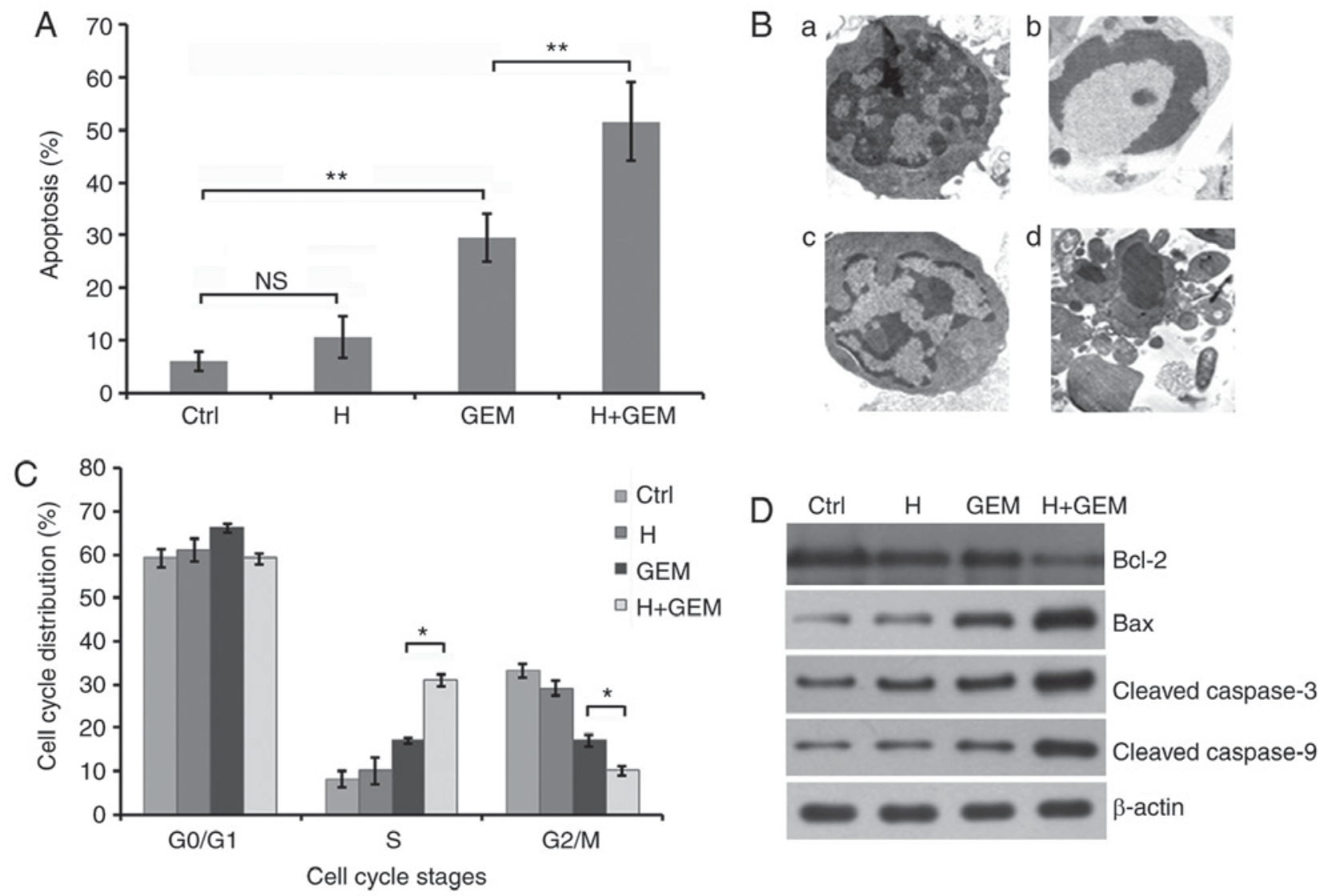

Figure 2. Hyperthermia increases GEM-induced cell apoptosis. (A) SW1990 cells were treated with hyperthermia at $42^{\circ} \mathrm{C}$ for 90 min, and then were treated with $5 \mu \mathrm{M}$ GEM for $24 \mathrm{~h}$. Cell apoptosis was assessed using an Annexin V-fluorescein isothiocyanate/propidium iodide assay. (B) Morphological changes of SW1990 cells were observed under a transmission electron microscope (magnification, x6,000), including the following groups: (a) Normal cells, (b) cells treated with hyperthermia alone, (c) cells treated with GEM alone and (d) cells treated with hyperthermia combined with GEM. (C) Cell cycle distributions of PC cells were detected using flow cytometry. (D) Protein expression of the apoptosis-associated proteins, B-cell lymphoma 2, Bcl-2-associated X protein, cleaved caspase- 3 and cleaved caspase- 9 were evaluated using western blot analysis using respective antibodies. $\beta$-actin was detected as internal reference. ${ }^{*} \mathrm{P}<0.05$ and ${ }^{* *} \mathrm{P}<0.01$ with comparisons shown by lines. NS, no significance; Ctrl, untreated group; H, treated with hyperthermia alone; GEM, treated with gemcitabine alone; H+GEM, treated with hyperthermia combined with gemcitabine.

combined with GEM compared with cells treated with GEM alone $(P<0.05)$, whilst the percentage of $P C$ cells at the $G_{2} / M$ stage was significantly decreased following treatment with $42^{\circ} \mathrm{C}$ hyperthermia combined with GEM compared with cells treated with GEM alone $(\mathrm{P}<0.05)$, implying that hyperthermia combined with GEM potentially blocked cells at the S-phase stage of cell cycle and thus accelerated apoptosis (Fig. 2C). To further determine the effect of hyperthermia on GEM-induced cell apoptosis, western blot analysis was performed to detect the levels of apoptosis-associated proteins. The results revealed that the expression of the anti-apoptotic protein $\mathrm{Bcl}-2$ in GEM-treated cells was downregulated when combined with hyperthermia treatment. By contrast, the pro-apoptosis proteins Bax, cleaved caspase- 3 and cleaved caspase- 9 demonstrated a notable increase in protein expression following treatment with hyperthermia combined with GEM compared with GEM treatment alone (Fig. 2D). The data indicated that hyperthermia increased the inhibitory effect of GEM on the viability of SW1990 cells, potentially by stimulating apoptosis, which may be mediated by the modulation of Bax, Bcl-2, cleaved caspase- 3 and cleaved caspase- 9 apoptotic factors.

Hyperthermia enhances GEM-induced apoptosis of SW1990 cells through ROS/JNK signaling. To further investigate the mechanism of hyperthermia enhancing GEM-induced apoptosis in PC cells, western blot analysis was performed to detect the protein expression of survivin, a protein specifically expressed at the $\mathrm{G}_{2} / \mathrm{M}$ stage (15), JNK and p-JNK, and a flow cytometry assay was used to detect the generation of ROS. It was revealed that the expression of survivin was downregulated in cells treated with $42^{\circ} \mathrm{C}$ hyperthermia combined with GEM treated cells compared with that in cells treated with GEM alone (Fig. 3A), suggesting that hyperthermia combined with GEM may affect the cell cycle by downregulating survivin. ROS/JNK signaling has been reported to be activated in a hyperthermic perfused amphibian heart and thus mediate cell apoptosis (16). In the present study, p-JNK was demonstrated to be notably upregulated following treatment with hyperthermia combined with GEM, relative to GEM treatment alone (Fig. 3A). Furthermore, it was revealed that the release of ROS during apoptosis in cells treated with hyperthermia in combination with GEM was significantly elevated compared with that in cells treated with GEM alone $(\mathrm{P}<0.01$; Fig. 3B). These data suggested that ROS/JNK signaling may be involved in the effects of hyperthermia on GEM-induced apoptosis in SW1990 cells.

To verify the function of ROS/JNK signaling inhyperthermia increasing GEM-induced apoptosis of PC SW1990 cells, a 
A
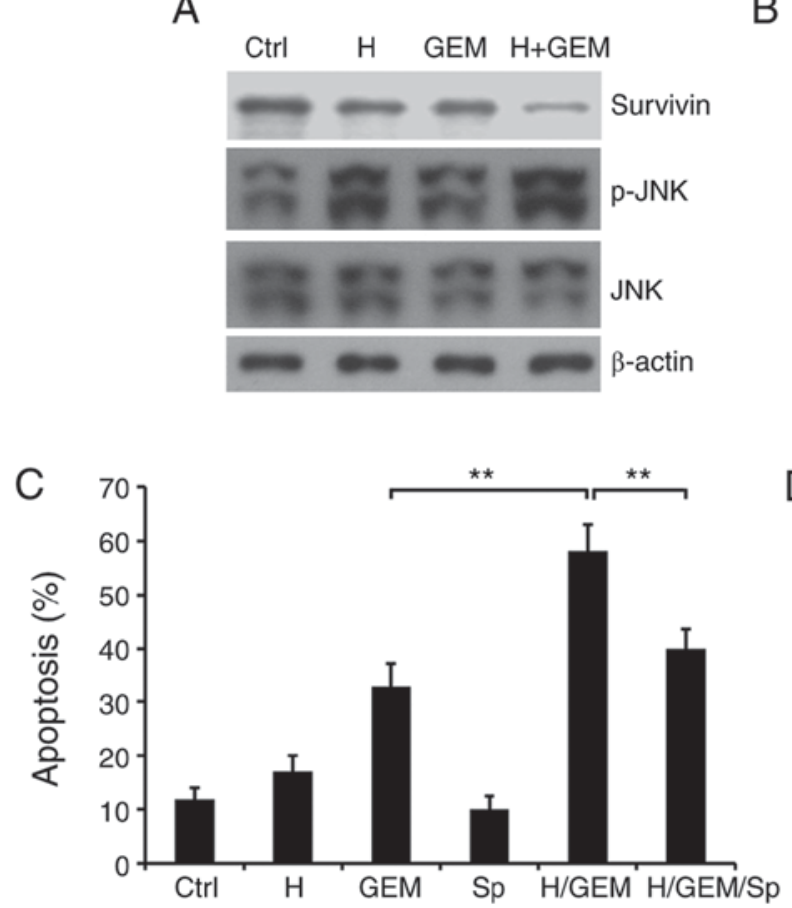

B
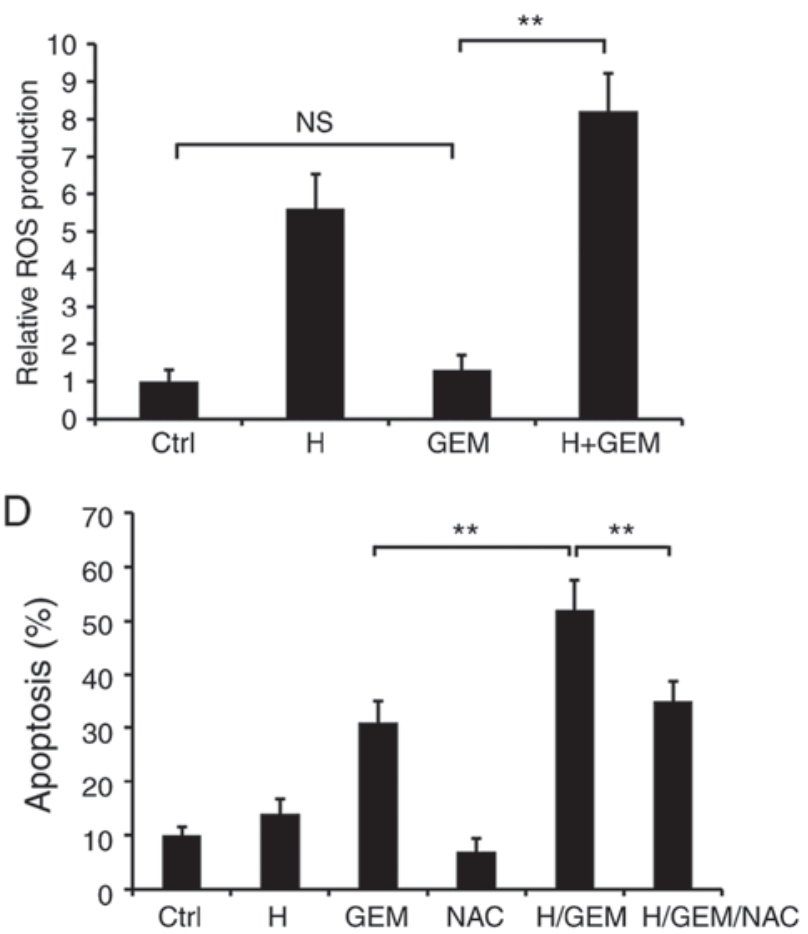

Figure 3. Involvement of survivin and ROS/JNK signaling in hyperthermia enhancing GEM-induced cell apoptosis. (A) Western blot analysis of survivin, JNK and p-JNK. $\beta$-actin was detected as internal reference. (B) Cells were treated with or without $42^{\circ} \mathrm{C}$ hyperthermia for 90 min, followed by treatment with $5 \mu \mathrm{M}$ GEM for $24 \mathrm{~h}$, and then ROS production was analyzed using 2',7'-dichlorodihydrofluorescein diacetate staining. (C) SW1990 cells were treated with or without hyperthermia for $90 \mathrm{~min}$ at $42^{\circ} \mathrm{C}$ in the presence or absence of the JNK inhibitor Sp600125 (10 $\left.\mu \mathrm{M}\right)$, and then were treated with $5 \mu \mathrm{M}$ GEM for $24 \mathrm{~h}$. Apoptosis was measured using an Annexin V-FITC/PI assay. (D) SW1990 cells were treated with or without hyperthermia for 90 min at $42^{\circ} \mathrm{C}$ in the presence or absence of the ROS inhibitor NAC (5 mM), and then were treated with $5 \mu \mathrm{M}$ GEM for 24 h. Apoptosis was measured using an Annexin V-FITC/PI assay. ${ }^{* *} \mathrm{P}<0.01$ with comparisons shown by lines. Ctrl, untreated normal cells; H, treated with hyperthermia alone; GEM, treated with gemcitabine alone; NAC, treated with N-acetyl-L-cysteine alone; H/GEM, treated with hyperthermia in addition to gemcitabine; H/GEM/NAC, treated with hyperthermia in the presence of N-acetyl-L-cysteine in addition to gemcitabine; Sp, treated with Sp600125 alone H/GEM/Sp, treated with hyperthermia in the presence of Sp600125 plus GEM; NS, no significance; ROS, reactive oxygen species; JNK, c-Jun-N-terminal kinase; p-, phosphorylated; FITC/PI, fluorescein isothiocyanatae/propidium iodide.

JNK inhibitor, Sp600125, was introduced in order to suppress JNK activation. It was revealed that Sp600125 significantly decreased the apoptotic effect of hyperthermia combined with GEM on SW1990 cells ( $\mathrm{P}<0.01$; Fig. 3C), indicating a positive effect of JNK on PC cell apoptosis. Furthermore, the ROS inhibitor NAC was applied to SW1990 cells in addition to hyperthermia treatment combined with GEM, and revealed that NAC was also able to significantly decrease the apoptotic effect of hyperthermia combined with GEM on SW1990 cells $(\mathrm{P}<0.01$; Fig. 3C), which implies a function of ROS in PC cell apoptosis mediated by hyperthermia treatment combined with GEM. In summary, it was demonstrated that hyperthermia enhanced GEM-induced cell apoptosis, potentially through ROS/JNK signaling.

\section{Discussion}

$\mathrm{PC}$ is an aggressive type of human cancer with a low 5-year survival rate $(1,17)$. One of the drugs used for the treatment of advanced PC is GEM (7). Although GEM is used as a first-line chemotherapeutic treatment for advanced PC, its efficacy still requires improvement $(7,8,18)$.

Hyperthermia treatment applied in a clinical setting includes whole body hyperthermia, local hyperthermia and intracellular hyperthermia $(19,20)$. Infrared radiation and extracorporeal circulation heating are commonly used for whole body hyperthermia; microwave thermotherapy, super-sound focusing thermotherapy, radiofrequency thermotherapy and endogenic field thermotherapy are commonly used for local hyperthermia $(19,20)$. In the present study, cells were treated with mild hyperthermia at $42^{\circ} \mathrm{C}$ in a $\mathrm{CO}_{2}$ incubator and it was revealed that mild hyperthermia at $42^{\circ} \mathrm{C}$ treatment may effectively enhance the sensitivity of PC SW1990 cells to GEM by inhibiting cell viability.

Apoptosis serves a critical function in chemotherapies in various cancer types (21). Whether hyperthermia increases the inhibitory effect of GEM on SW1990 cells viability by inducing apoptosis still requires further study. It has been demonstrated that the overexpression of heat shock protein 27 (HSP27) increases GEM sensitivity in PC cells through S-phase arrest and apoptosis (22) and HSP27 expression may be upregulated by hyperthermia in osteosarcoma cells and PC cells $(22,23)$. Therefore, it may be that HSP27 is involved in the effect of hyperthermia on the sensitivity of PC SW1990 cells to GEM, which requires further investigation. Additionally, in the present study, it was revealed that hyperthermia increased GEM-induced cell apoptosis. To explore the molecular mechanism underlying the effect of hyperthermia combined with GEM on the inhibition of viability of and the induction of apoptosis in SW1990 cells, the present study detected the expression levels of apoptosis-associated proteins (including Bcl-2, Bax, cleaved caspase-3 and cleaved caspase-9). Anti-apoptosis protein Bcl-2 and pro-apoptosis protein $\mathrm{Bax}$, which are $\mathrm{Bcl}-2$ family proteins, 
regulate mitochondrial permeability to affect apoptosis through an intrinsic pathway (24). Cleaved caspase-3 and caspase-9, which are known as mature or activated caspase-3 and caspase- 9 , are critical mediators of cell apoptosis (25). All caspases require cleavage adjacent to aspartates to liberate one large and one small subunit, which associate with an a2b2 tetramer to form the active enzyme (26). Caspase enzymes are able to cleave the death substrate poly ADP-ribose polymerase to a specific $85 \mathrm{kDa}$ form observed during apoptosis (25). The results of the expression of these apoptosis-associated proteins in the present study were consistent with the promotion of apoptosis and indicated that hyperthermia combined with GEM induced apoptosis in SW1990 cells by downregulating the expression of Bcl-2 and upregulating the expression of Bax, caspase 3 and caspase 9 .

Survivin is a type of anti-apoptosis protein, which is specifically expressed in cells at the $\mathrm{G}_{2} / \mathrm{M}$ stage (12). It has been reported that survivin knockdown PC stem cells demonstrated a greater sensitivity to GEM compared with normal PC stem cells, and GEM-induced cell death was significantly promoted (27), which suggested an association between survivin and the effect of hyperthermia on GEM-induced apoptosis. In the present study, it was revealed that the majority of PC cells treated with hyperthermia combined with GEM were arrested at the S-phase stage instead of entering the $G_{2} / M$ stage, and possessed a larger percentage of apoptotic cells compared with the control group. Additionally, the downregulated expression of survivin may indicate that hyperthermia treatment combined with GEM affects the cycle of PC cells by downregulating survivin, thereby accelerating the apoptosis of PC cells.

ROS are active forms of oxygen, produced as by-products of cellular metabolism (28). Previous studies have revealed that the slight upregulation of ROS may enhance cell viability, whereas excessive amounts of ROS may result in cell apoptosis (29). A majority of cancer therapeutic methods damage cells due to the generation of a substantial quantity of ROS resulting in cell death $(30,31)$. ROS function as intracellular messengers and affect protein structure and function by oxidizing crucial amino acid residues (32). It was hypothesized as to whether hyperthermia combined with GEM resulted in redundant ROS thereby triggering PC cell apoptosis. It was revealed that ROS production was significantly increased by hyperthermia treatment combined with GEM compared with GEM treatment alone, suggesting that ROS may be associated with cell apoptosis induced by hyperthermia combined with GEM treatment. It is widely known that ROS may affect numerous signaling pathways (33). Mitogen-activated protein kinase (MAPK) signaling transduction is one of the signaling pathways modulated by ROS $(34,35)$. Extracellular signal-regulated kinases (ERKs), p38 MAPKs and JNKs are three critical protein kinases involved in MAPK signaling pathways (36). ERK cascades are commonly associated with cell survival and may be activated by growth or survival factors. Whereas, p38 MAPK and JNK pathways are often associated with pro-apoptotic effects $(37,38)$. ROS has been demonstrated to be able to activate apoptosis signal-regulated kinase 1 and induce the activation of the JNK cascade and apoptosis $(39,40)$. JNK signaling initiates apoptosis potentially through two different methods. One method is to directly regulate apoptosis-associated proteins including $\mathrm{Bcl}-2$ proteins (41), whereas an indirect method is to translocate to the nucleus where it regulates the activity of transcription factors, including c-Jun, and then regulates the expression of apoptotic genes $(42,43)$. As a member of MAPK family, JNK is involved in cell apoptosis $(44,45)$. In the present study, the expression of JNK and p-JNK were detected, and demonstrated upregulation following treatment with hyperthermia combined with GEM compared with GEM treatment alone. Additionally, the upregulation of p-JNK is involved in the activation of JNK signaling (46). Furthermore, the JNK inhibitor, Sp600125, was used, and significantly decreased the apoptosis of PC SW1990 cells compared with cells treated with hyperthermia and GEM. Therefore, it was considered that hyperthermia combined with GEM enhanced PC cell apoptosis through JNK signaling. Finally, a ROS inhibitor, NAC, was introduced in order to verify the association between JNK and PC cell apoptosis. It was concluded that hyperthermia increased the GEM sensitivity of PC SW1990 cells by inhibiting cell growth and inducing apoptosis via ROS/JNK signaling, which may be significant for improving therapy for patients with PC. However, the exact association between hyperthermia and GEM mediated ROS production, apoptosis and activation of JNK signal transduction requires further investigation.

\section{Acknowledgements}

Not applicable.

\section{Funding}

This project was supported by Hangzhou Science and Technology Development Plan project (grant no. 20162013A01).

\section{Availability of data and materials}

The analyzed datasets generated during the study are available from the corresponding author on reasonable request.

\section{Authors' contributions}

HJ and SM made major contributions in the conception and design of the research and revision of the manuscript for important intellectual content and the funding was obtained by SM. Acquisition of data was performed by YZ and JY. $\mathrm{YZ}$ and $\mathrm{XZ}$ were the major contributors in the analysis and interpretation of data and statistical analysis. Drafting the manuscript and revising it critically for important intellectual content were performed by HJ.

\section{Ethics approval and consent to participate}

Not applicable.

\section{Patient consent for publication}

Not applicable.

\section{Competing interests}

The authors declare that they have no competing interests. 


\section{References}

1. Worni M, Guller U, White RR, Castleberry AW, Pietrobon R, Cerny T, Gloor B and Koeberle D: Modest improvement in overall survival for patients with metastatic pancreatic cancer: A trend analysis using the surveillance, epidemiology, and end results registry from 1988 to 2008. Pancreas 42: 1157-1163, 2013.

2. Ferlay J, Shin HR, Bray F, Forman D, Mathers C and Parkin DM Estimates of worldwide burden of cancer in 2008: GLOBOCAN 2008. Int J Cancer 127: 2893-2917, 2010.

3. Ottaiano A, Capozzi M, De Divitiis C, De Stefano A, Botti G, Avallone A and Tafuto S: Gemcitabine mono-therapy versus gemcitabine plus targeted therapy in advanced pancreatic cancer: A meta-analysis of randomized phase III trials. Acta Oncol 56 377-383, 2017.

4. Bednar F and Simeone DM: Recent advances in pancreatic surgery. Curr Opin Gastroenterol 30: 518-523, 2014.

5. Ghaneh P,Smith R, Tudor-Smith C, Raraty M and Neoptolemos JP: Neoadjuvant and adjuvant strategies for pancreatic cancer. Eur J Surg Oncol 34: 297-305, 2008.

6. Viaud J, Brac C, Artru P, Le Pabic E, Leconte B, Bodère A, Pracht M, Le Sourd S, Edeline J and Lièvre A: Gemcitabine as second-line chemotherapy after Folfirinox failure in advanced pancreatic adenocarcinoma: A retrospective study. Dig Liver Dis 49: 692-696, 2017.

7. Massari F, Santoni M, Ciccarese C, Brunelli M, Conti A, Santini D, Montironi R, Cascinu S and Tortora G: Emerging concepts on drug resistance in bladder cancer: Implications for future strategies. Crit Rev Oncol Hematol 96: 81-90, 2015.

8. Immordino ML, Brusa P, Rocco F, Arpicco S, Ceruti M and Cattel L: Preparation, characterization, cytotoxicity and pharmacokinetics of liposomes containing lipophilic gemcitabine prodrugs. J Control Release 100: 331-346, 2004.

9. Kim CE, Lim SK and Kim JS: In vivo antitumor effect of cromolyn in PEGylated liposomes for pancreatic cancer. J Control Release 157: 190-195, 2012.

10. Maeda H, Wu J, Sawa T, Matsumura Y and Hori K: Tumor vascular permeability and the EPR effect in macromolecular therapeutics: A review. J Control Release 65: 271-284, 2000.

11. Kirui DK, Celia C, Molinaro R, Bansal SS, Cosco D, Fresta M, Shen $\mathrm{H}$ and Ferrari M: Mild hyperthermia enhances transport of liposomal gemcitabine and improves in vivo therapeutic response. Adv Healthc Mater 4: 1092-1103, 2015.

12. Shamir ER and Ewald AJ: Adhesion in mammary development Novel roles for E-cadherin in individual and collective cell migration. Curr Top Dev Biol 112: 353-382, 2015.

13. Nicoletti I, Migliorati G, Pagliacci MC, Grignani F and Riccardi C: A rapid and simple method for measuring thymocyte apoptosis by propidium iodide staining and flow cytometry. J Immunol Methods 139: 271-279, 1991.

14. Hobot J, Carlemalm E. Villiger W and Kellenberger E: Periplasmic Gel: New concept resulting from the reinvestigation of bacterial cell envelope ultrastructure by new methods J Bacteriol 160: 143-152, 1984

15. Li E, Ambrosini G, Chu EY, Plescia J, Tognin S, Marchisio PC and Altieri DC: Control of apoptosis and mitotic spindle checkpoint by survivin. Nature 396: 580-584, 1998.

16. Gaitanaki C, Mastri M, Aggeli IK and Beis I: Differential roles of p38-MAPK and JNKs in mediating early protection or apoptosis in the hyperthermic perfused amphibian heart. J Exp Biol 211: 2524-2532, 2008.

17. Siegel RL, Miller KD and Jemal A: Cancer statistics, 2016. CA Cancer J Clin 66: 7-30, 2016.

18. de Sousa Cavalcante L and Monteiro G: Gemcitabine: Metabolism and molecular mechanisms of action, sensitivity and chemoresistance in pancreatic cancer. Eur J Pharmacol 741: 8-16, 2014

19. van der Zee J: Heating the patient: A promising approach? Ann Oncol 13: 1173-1184, 2002

20. Falk MH and Issels RD: Hyperthermia in oncology. Int J Hyperthermia 17: 1-18, 2001.

21. San-Miguel IC B, Vallejo D, Álvarez M, Prieto J, González-Gallego J and Tuñón MJ: Melatonin modulates the autophagic response in acute liver failure induced by the rabbit hemorrhagic disease virus. J Pineal Res 56: 313-321, 2014.

22. Guo Y, Ziesch A, Hocke S, Kampmann E, Ochs S, De Toni EN, Göke B and Gallmeier E: Overexpression of heat shock protein 27 (HSP27) increases gemcitabine sensitivity inpancreatic cancer cells through S-phase arrest and apoptosis. J Cell Mol Med 19: 340-350, 2015
23. Nakajima $K$, Yanagawa $T$, Watanabe $H$ and Takagishi $K$ : Hyperthermia reduces migration of osteosarcoma by suppression of autocrine motilityfactor. Oncol Rep 28: 1953-1958, 2012.

24. Jin S, Shen JN, Wang J, Huang G and Zhou JG: Oridonin induced apoptosis through Akt and MAPKs signaling pathways in human osteosarcoma cells. Cancer Biol Ther 6: 261-268, 2007.

25. Cheng Y, Qiu F, Ye YC, Tashiro S, Onodera S and Ikejima T: Oridonin induces $\mathrm{G} 2 / \mathrm{M}$ arrest and apoptosis via activating ERK-p53 apoptotic pathway and inhibiting PTK-Ras-Raf-JNK survival pathway in murine fibrosarcoma L929 cells. Arch Biochem Biophys 490: 70-75, 2009.

26. Shi Y: Caspase activation: Revisiting the induced proximity model. Cell 117: 855-858, 2004.

27. Takeda H, Okada M, Suzuki S, Kuramoto K, Sakaki H, Watarai H, Sanomachi T, Seino S, Yoshioka T and Kitanaka C: Rho-associated protein kinase (ROCK) inhibitors inhibit survivin expression and sensitize pancreatic cancer stem cells to gemcitabine. Anticancer Res 36: 6311-6318, 2016.

28. Filomeni G, De Zio D and Cecconi F: Oxidative stress and autophagy: The clash between damage and metabolic needs. Cell Death Differ 22: 377-388, 2015.

29. Renschler MF: The emerging role of reactive oxygen species in cancer therapy. Eur J Cancer 40: 1934-1940, 2004.

30. Toler SM, Noe D and Sharma A: Selective enhancement of cellular oxidative stress by chloroquine: Implications for the treatment of glioblastoma multiforme. Neurosurg Focus 21: E10, 2006.

31. Scandalios JG: Oxidative stress: Molecular perception and transduction of signals triggering antioxidant gene defenses. Braz J Med Biol Res 38: 995-1014, 2005.

32. Son Y, Cheong YK, Kim NH, Chung HT, Kang DG and Pae HO: Mitogen-activated protein kinases and reactive oxygen species: How can ROS activate MAPK pathways? J Signal Transduct 2011: 792639, 2011

33. Dhillon AS, Hagan S, Rath O and Kolch W: MAP kinase signalling pathways in cancer. Oncogene 26: 3279-3290, 2017

34. Liu QR, Liu JM, Chen Y, Xie XQ, Xiong XX, Qiu XY, Pan F, Liu D, Yu SB and Chen XQ: Piperlongumine inhibits migration of glioblastoma cells via activation of ROS-dependent p38 and JNK signaling pathways. Oxid Med Cell Longev 2014: 653732, 2014.

35. Goldsmith EJ, Min X, He H and Zhou T: Structural studies of MAP kinase cascade components. Methods Mol Biol 661: 223-237, 2010.

36. Johnson GL and Lapadat R: Mitogen-activated protein kinase pathways mediated by ERK, JNK, and p38 protein kinases. Science 298: 1911-1912, 2002.

37. Lencioni R, Chen XP, Dagher L and Venook AP: Treatment of intermediate/advanced hepatocellular carcinoma in the clinic: How can outcomes be improved? Oncologist 15 (Suppl 4): S42-S52, 2010

38. Katz M, Amit I and Yarden Y: Regulation of MAPKs by growth factors and receptor tyrosine kinases. Biochim Biophys Acta 1773: 1161-1176, 2007.

39. Tobiume K, Matsuzawa A, Takahashi T, Nishitoh H, Morita K, Takeda K, Minowa O, Miyazono K, Noda T and Ichijo H: ASK1 is required for sustained activations of JNK/p38 MAP kinases and apoptosis. EMBO Rep 2: 222-228, 2001.

40. Takeda K, Noguchi T, Naguro I and Ichijo H: Apoptosis signal-regulating kinase 1 in stress and immune response. Annu Rev Pharmacol Toxicol 48: 199-225, 2008.

41. Wu CC and Bratton SB: Regulation of the intrinsic apoptosis pathway by reactive oxygen species. Antioxid Redox Signal 19: 546-558, 2013.

42. Dhanasekaran DN and Reddy EP: JNK signaling in apoptosis. Oncogene 27: 6245-6251, 2008.

43. Chang L and Karin M: Mammalian MAP kinase signalling cascades. Nature 410: 37-40, 2001

44. Suzuki S, Okada M, Shibuya K, Seino M, Sato A, Takeda H, Seino S, Yoshioka T and Kitanaka C: JNK suppression of chemotherapeutic agents-induced ROS confers chemoresistance on pancreatic cancer stem cells. Oncotarget 6: 458-470, 2015.

45. Sun ZL, Dong JL and Wu J: Juglanin induces apoptosis and autophagy in human breast cancer progression via ROS/JNK promotion. Biomed Pharmacother 85: 303-312, 2017.

46. Weston CR and Davis RJ: The JNK signal transduction pathway. Curr Opin Genet Dev 12: 14-21, 2002. 